Maciej Delnicki*, Anna Bielska*, Agnieszka Turek*

\title{
Restrictions in Development of Rural Areas Resulting from Defective Structure of Cadastral Parcels
}

\begin{abstract}
Rural areas have been subjected to constant transformations for centuries. The current state of the settlement network and image of Polish space has resulted from a number of political and legal transformations along with economic and social processes. With the development of civilization, the factors determining the location of new residential building developments and the function of rural areas have changed. The importance of non-agricultural production functions and consumption functions has currently increased at a cost of a declining share of agricultural production.

The objective of the study was to determine the degree to which the structure of cadastral parcels restricts the possibilities of development of different functions in rural areas. The research was conducted in the Nasielsk commune. Planning documents were analyzed to determine the directions of development of the commune. The structure of all of the commune's cadastral parcels was analyzed to determine their surface areas and shapes. The layout of selected agricultural farms was determined, with a consideration for the area of the farms, the number of parcels, their surface areas, and their shapes.

According to the research, the defective structure of cadastral parcels largely restricts not only the development of agriculture but also the rational management of parcels allocated for building development. Moreover, it facilitates a natural forest succession, which is favorable from an environmental point of view but undoubtedly constitutes an obstacle in the use of arable land.
\end{abstract}

Keywords: Nasielsk, development of rural areas, structure of cadastral parcels

Received: 29 April 2018; accepted: 25 July 2018

* Warsaw University of Technology, Faculty of Geodesy and Cartography, Warsaw, Poland 


\section{Introduction}

Rural areas have been subjected to continuous transformations for centuries. The current state of the settlement network and Polish space has resulted from a number of political, legal, economic, and social processes. Together with civilizational development, the factors determining the locations of new residential building development as well as the function fulfilled by rural areas have changed. In modern times, the role of non-agricultural production and consumption functions is increasing in rural areas at a cost of the decreasing contribution of agricultural production. The process is a result of deruralization, desagrarization, the development of a new model of agriculture, and social changes progressing from the early 20th century [1]. Its intensification occurred after 1989 under the conditions of planning governance of the communes, imperfect legal norms, and free market economy. The problem of uncontrolled building development in rural areas without the consideration of the rules of sustainable development became more serious. The progressing globalization triggering the spiral of competitiveness strongly affects agriculture. It stimulates urbanization, which according to [2] leads to the "loss of entire villages, displacement of agriculture from cities, transferring social costs of the environmental degradation and environmental protection to rural areas," among other things. As emphasized by [3], the aggravation of the occurring processes in the conditions of society's increase in wealth will result both in the loss of spatial order and the deterioration of the economic properties of management and values of the natural environment [3].

Among the many factors affecting the production and economic results in agriculture, the development of land layout is of particular importance. In the territory of Poland, it is far from optimal. Therefore, rural areas require structural changes in the scope of the size of farms, their spatial and infrastructural structure, or their land layout (among others) [4,5]. A farm that is properly organized in areal and spatial terms allows for the implementation of socio-economic and production tasks in rural areas [6]. The excessive fragmentation of land on individual farms in combination with their small sizes constitutes to a serious problem and a limitation on their development; these factors contribute to a decrease in the profitability of agricultural production $[7,8]$. The land fragmentation parameters of farms are usually characterized based on values such as the average surface area of the plot included in the composition of agricultural farms, the number of plots forming a unit, or the number of plots forming an agricultural farm [8-11].

Structural and landscape changes can be observed in the vicinity of rural settlement units in Poland. The continuous fragmentation of plots is observed, resulting from demographic, economic, and social transformations [12] as well as the expansion of urban development onto rural areas (which has recently intensified). Changes in the spatial structures of areas allocated for new housing development often occur spontaneously and are unplanned. New spatial forms are introduced in unad- 
justed spatial-areal structures that do not meet the requirements resulting from the new functions [13].

In sustainable spatial planning with the available improved spatial databases [14], the historical layouts of rural areas, the ecological-spatial models of entire communes, and the needs of the residents should be considered $[15,16]$.

The objective of the study was to determine the degree to which the structures of registered plots limit the possibilities of developing different functions in rural areas (particularly, the residential function).

\section{Characteristics of Study Area, Materials, and Methods}

The research was conducted in the urban-rural commune of Nasielsk located in the central part of the Mazowieckie Voivodeship in the north Mazowsze region on the northeastern edge of the Ciechanowska Plateau (Fig. 1).

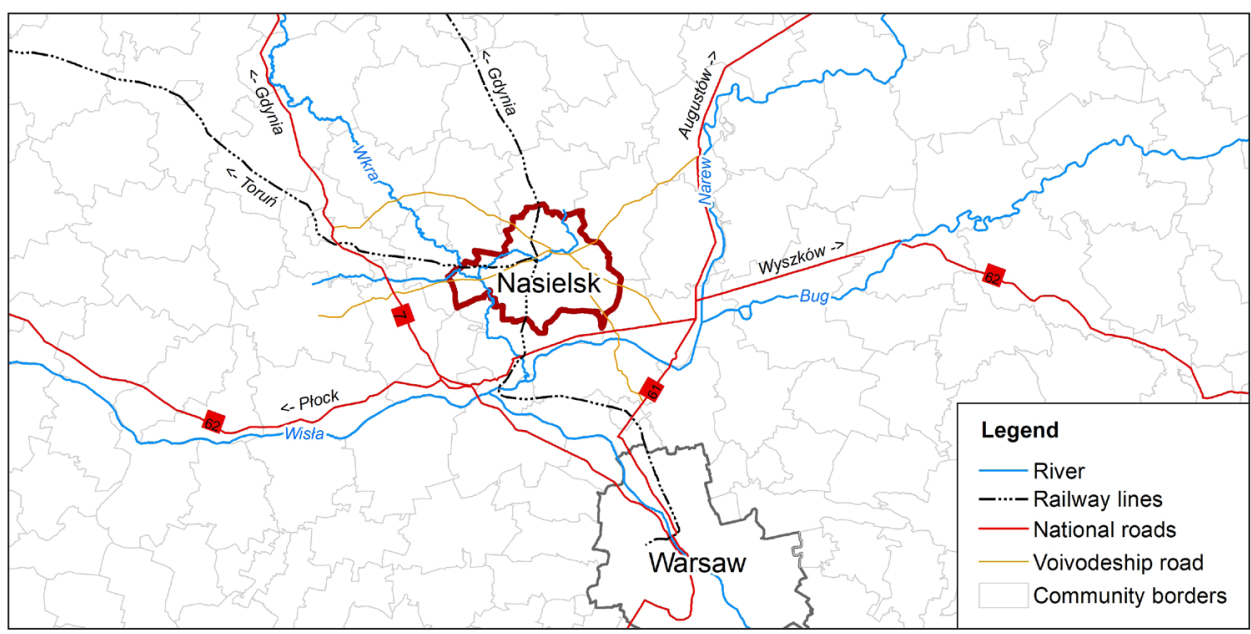

Fig. 1. Location of study area

Source: own elaboration

The commune occupies an area of 19,285 ha, and the city contains 1,267 ha. The commune and city have approximately 19,930 and 7705 residents, respectively [17]. The magistral Gdynia - Warszawa rail line runs through the commune in a northsouth orientation, with a branching in the village of Pieścirogi Nowe towards Sierpiec and Torun. Three voivodeship roads run through the commune and city. The close vicinity also includes the following national roads: Hwy. 7 (Warszawa Gdańsk), Hwy. 61 (Warszawa - Augustów), and Hwy. 62 (Inowrocław - Siemiatycze). Its relatively close distance from Warsaw $(60 \mathrm{~km})$, convenient transportation, 
and environmental and landscape values in the area of the Wkra River make the commune an attractive locale for housing and holiday infrastructure development based on individual investments. The basic function of the commune, however, is agriculture. Arable land constitutes $89.3 \%$ of the area of the commune and $83.1 \%$ of the area of the city (with a small forest area). The suitability of its soil for agricultural production is moderate. The majority of its arable land (more than $90 \%$ ) is under use in individual farms. The main center concentrating services for agriculture is the city of Nasielsk [18].

The existing building development, particularly housing, is located along the access roads (so-called linear settlement, constituting the most frequently occurring type of village in Poland). The developing building development, both residential and settlement, is mainly continued along roads, like in the Morgi district. Unfortunately, the unfavourable parameters of plots, and particularly their width, in many cases cause a change in the layouts of building development which encroaches deep into the plots, forcing their transverse divisions, like in Pieścirogi Nowe district, where the direct vicinity of a railway station contributed to intensive housing development (Fig. 2).

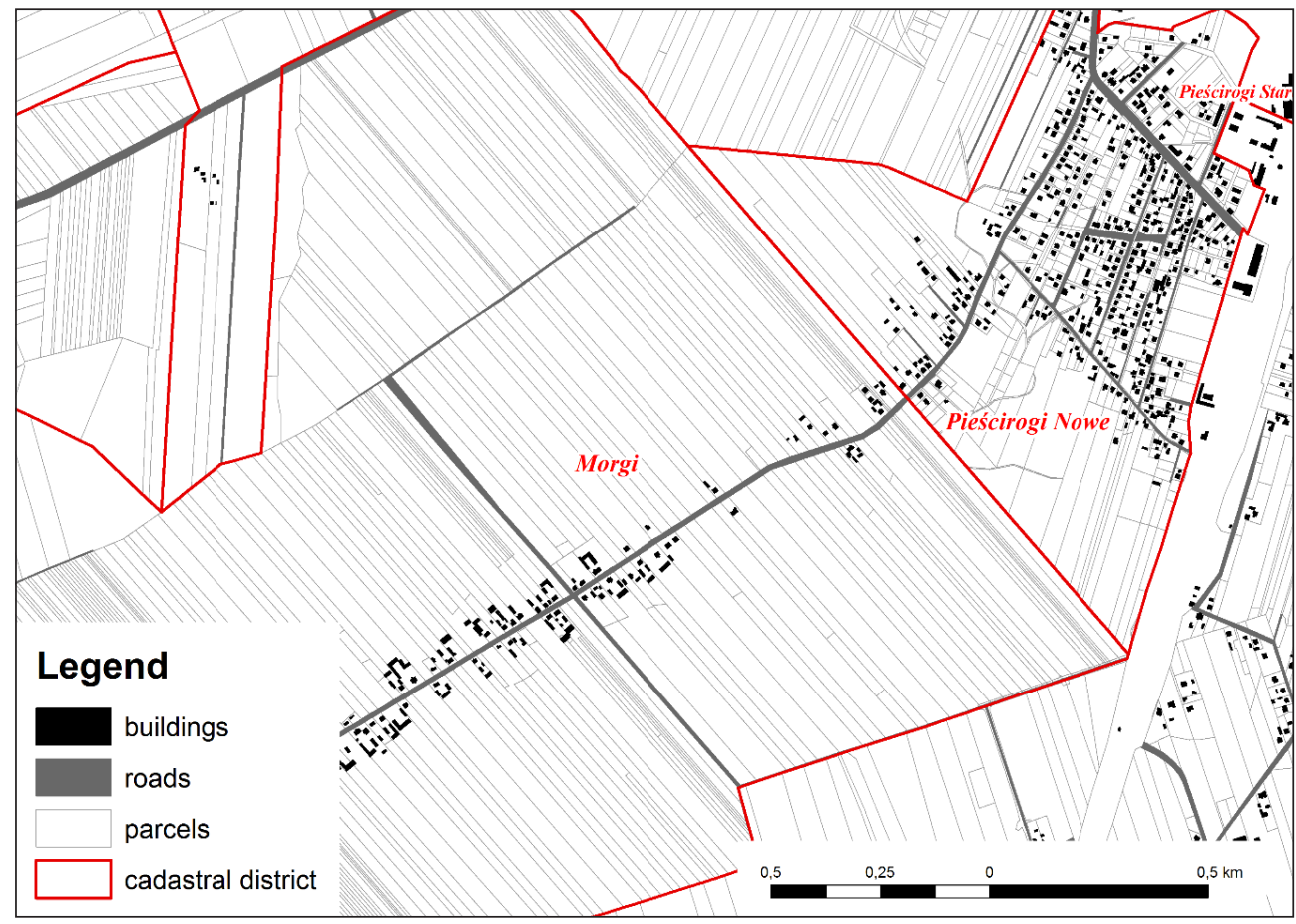

Fig. 2. Location of building development in the selected fragment of the Nasielsk commune 
After taking into account the local spatial differences resulting from the natural, socio-economic and technical-infrastructural conditions, functional predispositions, and role of the area in the economic development of the commune, functional and spatial zones have been distinguished:

- urban area - intensive development of settlement, service, and production functions based on a shaped urban center with settlement covers the city of Nasielsk and its neighboring regions;

- tourism and leisure zone - based on the favorable natural and landscape conditions of the region and its current investment; it covers the area of the Wkra River valley and large forest complexes along with the villages in their immediate vicinity;

- the agricultural zone - with a dominant agricultural function based on the potential of the agricultural production space with more favorable soil conditions;

- agri-forest zone - covering the remaining area of the commune characterized by less favorable soil conditions of the agricultural production space and a larger share of forests and wooded areas.

The study employed planning documents and cartographic and descriptive materials obtained from the state geodesic and cartographic resource; i.e.,

- collection of data on land and building register, including map of land and building register,

- data base of topographic objects (BDOT500),

- orthophotomap,

- study of conditions and directions of spatial development of city and commune of Nasielsk (2010),

- local spatial development plans,

- other descriptive data, including the Strategy of the Sustainable Development of the Nasielsk commune by 2020.

For the purpose of determining the degree of the effect of the structure of the registered plots on the limitation of the possibilities of the development of different functions in rural areas, planning documents specifying the directions of the development of the commune were analyzed, and the structure of all of the registered plots was investigated (including their surface areas and shapes). Detailed research involved an analysis of four basic properties of the plot layout. The land layout of the agricultural farms (registered units) was determined with consideration of the surface areas of the farms and number of plots along with their surface areas and shapes. The research covered only the rural districts (excluding the city of Nasielsk).

The study employed the ArcGIS tool packages that permitted the collection, analysis, and processing of the spatial data. 


\section{Analysis of Structure of Plots and Agricultural Farms}

The structure of the plots and agricultural farms was analyzed based on a survey of the registered units disclosed in plot indices prepared on February 15, 2018. The analysis covered a total of 61 districts, including 19,783 registered plots and 8,060 registered units. Natural persons own 16,337 registered plots with a total area of 18,786 ha, which constitutes $95 \%$ of the total surface area of the commune. Among the registered units belonging to natural persons, only about $40 \%(3,134)$ of the registered units have arable land of more than 1 ha in the Nasielsk commune (these most likely constitute agricultural farms). Among these farms, 73\% are composed of 1-3 plots, and 5\% have 10 and more plots (Tab. 1).

Table 1. Farm fragmentation by numbers or plots

\begin{tabular}{|c|c|c|c||}
\hline $\begin{array}{c}\text { Number of plots } \\
\text { belonging to one } \\
\text { registered unit } \\
\text { [items] }\end{array}$ & $\begin{array}{c}\text { Number of } \\
\text { registered units } \\
\text { [items] }\end{array}$ & $\begin{array}{c}\text { Contribution in } \\
\text { total number of } \\
\text { registered units [\%] }\end{array}$ & $\begin{array}{c}\text { Contribution in total } \\
\text { surface area of plots } \\
\text { [\%] }\end{array}$ \\
\hline \hline 1 & 1108 & 35.4 & 24.0 \\
\hline $2-3$ & 1190 & 38.0 & 31.9 \\
\hline $4-5$ & 380 & 12.1 & 14.8 \\
\hline $6-9$ & 298 & 9.5 & 15.6 \\
\hline more than 9 & 159 & 5.1 & 13.8 \\
\hline Total & 3134 & 100.0 & 100.0 \\
\hline
\end{tabular}

Source: own elaboration based on data from land and building register

Based on the comparison presented in Table 1, the problem of the number of plots can be considered insubstantial; however, considering particular districts, it should be noted that some districts (e.g., the Głoodowo Wielkie, Morgi, and Studzianki districts) include many farms composed of ten or more plots (Fig. 3).

In reference to the surface area of the farms, it should be emphasized that farms of up to 10 ha are predominant (61\% of the surface area of the farms). They constitute a total of $88 \%$ of all farms (Fig. 4). The commune includes 66 farms with surface areas of $20-50$ ha and four farms with more than 50 ha. Farms with more than 20 ha occupy 12\% of the total surface area of the farms (e.g.,: the Nowa Wrona, Pianowo Daczki, and Popowo Borowe districts). This is a relatively low value, but such farms have the greatest chance for further development of agricultural production. Nonetheless, the fact that they are composed of approximately a dozen small plots (up to 2 ha) (Fig. 5) makes the rational development of agricultural production difficult. The analysis of the structure of the plots by surface area showed that plots of up to 1 ha constitute $55 \%$ of their total number, whereas they occupy $14 \%$ of the total surface area (Fig. 6). 


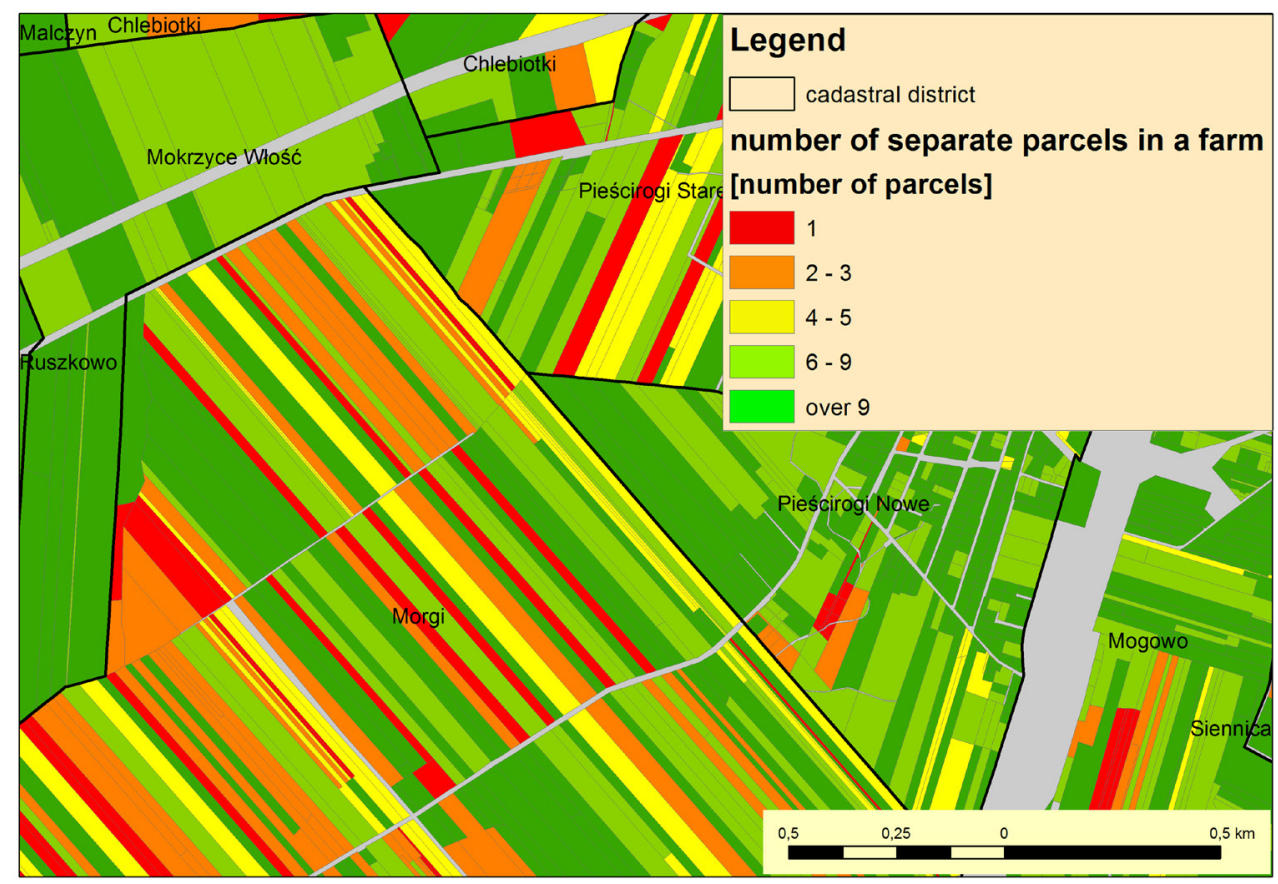

Fig. 3. Farm structure by number of plots on in selected fragment of Nasielsk commune Source: own elaboration based on data from land and building register

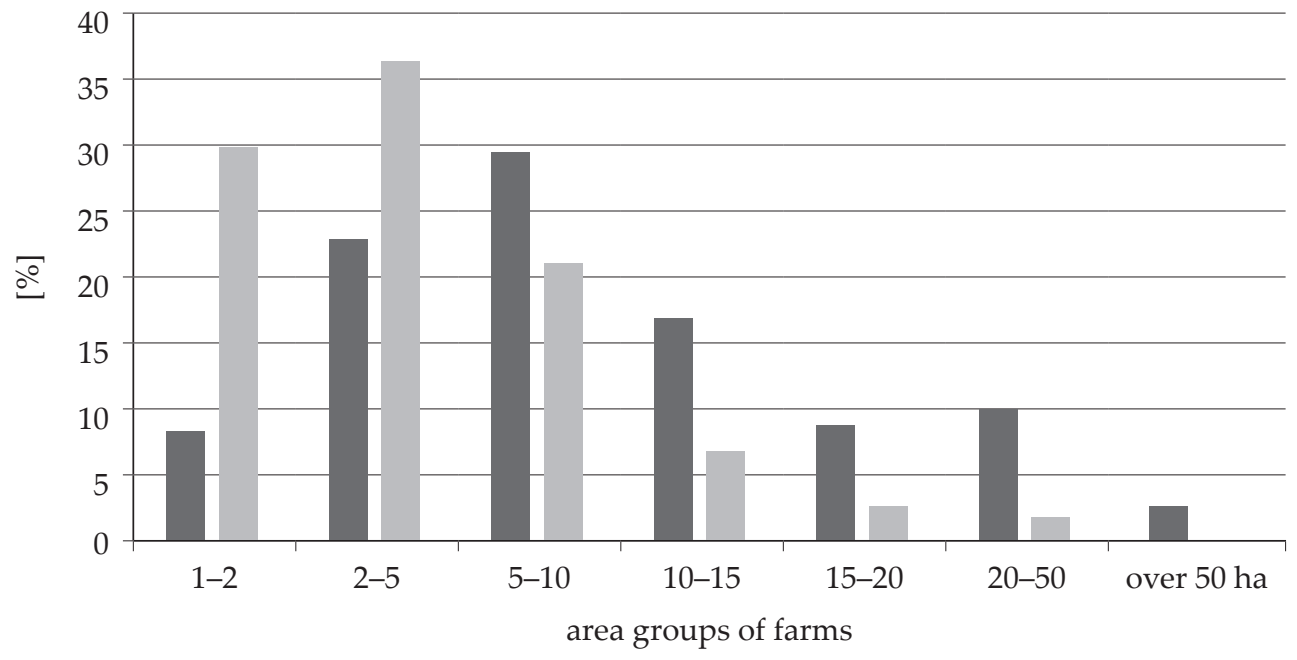

share in the total area of farms [\%] share in the total number of farms [\%]

Fig. 4. Structure of farms by areal groups

Source: own elaboration based on data from land and building register 


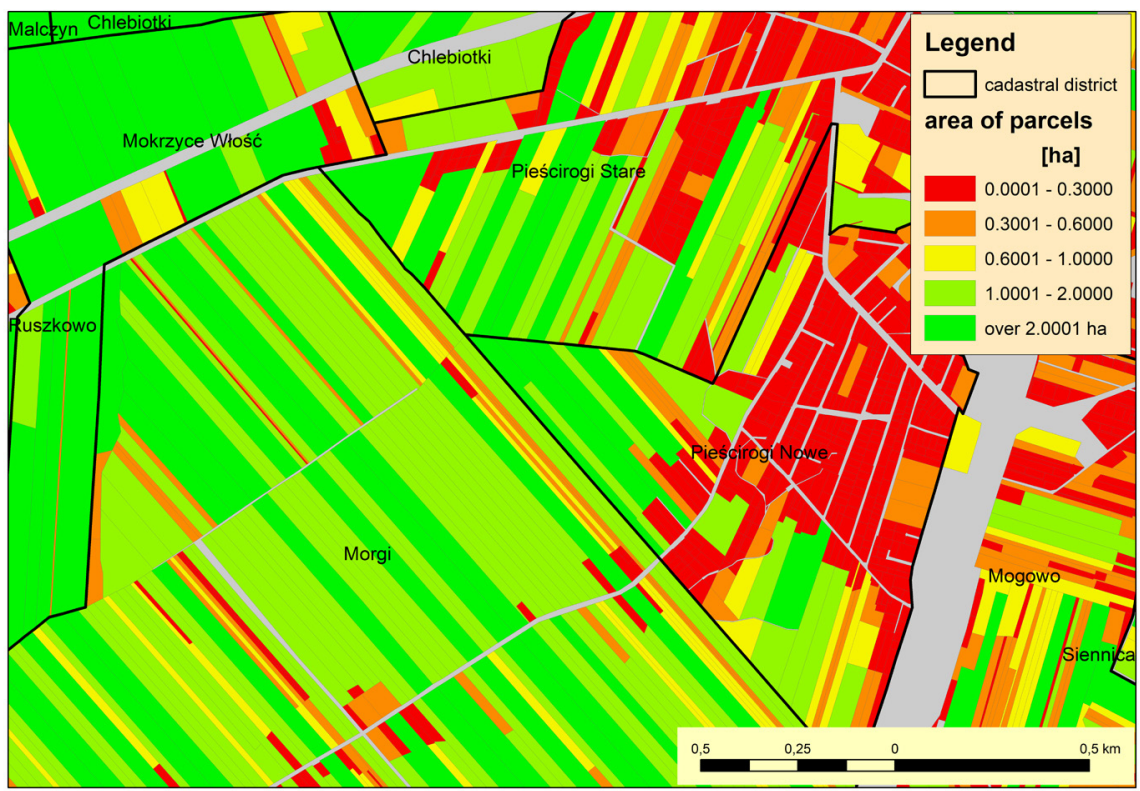

Fig. 5. Structure of registered plots by surface area in selected fragment of Nasielsk commune Source: own elaboration based on data from land and building register

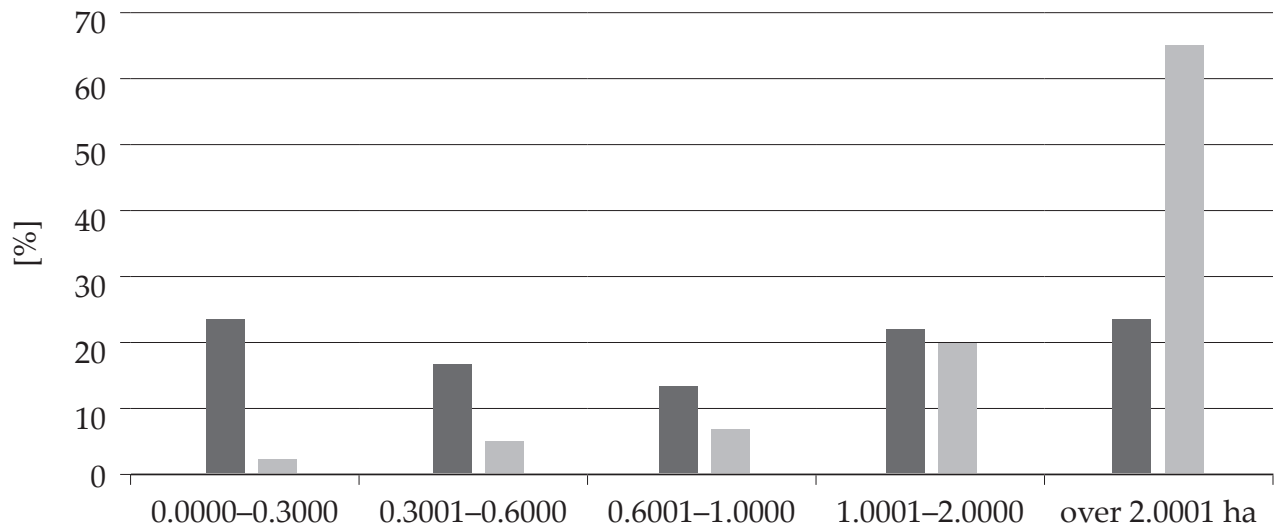

share in the total area of parcels [\%] share in the total number of parcels [\%]

Fig. 6. Structure of plots by surface area

Source: own elaboration based on data from land and building register

An equally unfavorable parameter is the shapes of the registered plots as well as their widths and elongations. Over the study area, more than $30 \%$ of the plots have widths of less than $20 \mathrm{~m}$ (Fig. 7) and elongations greater than 1:10 (Fig. 8). 


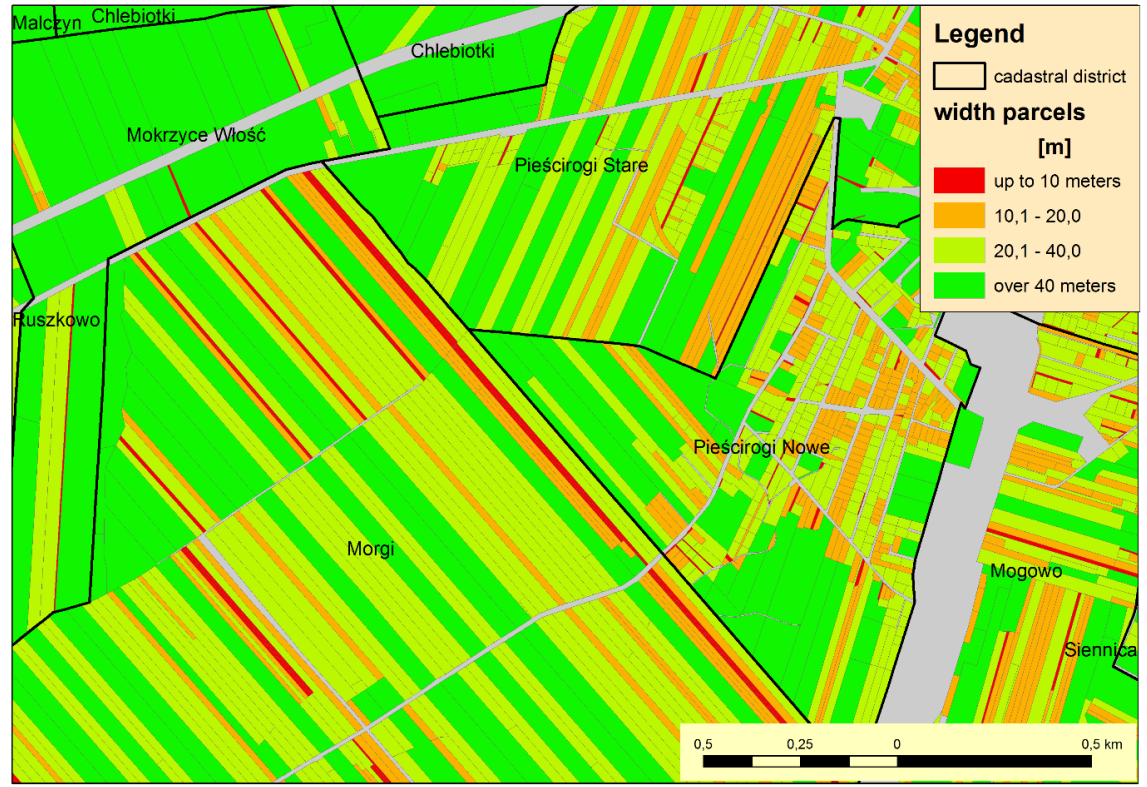

Fig. 7. Structure of registered plots by width in selected fragment of Nasielsk commune Source: own elaboration based on data from land and building register

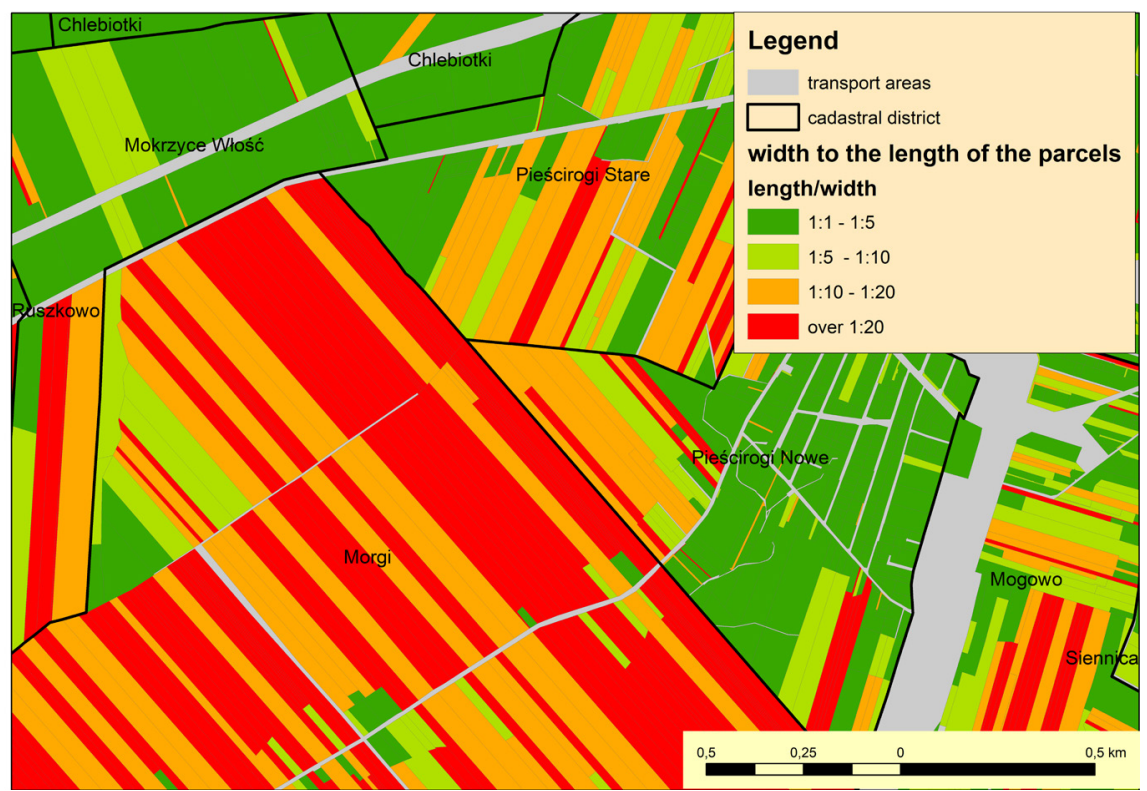

Fig. 8. Structure of registered plots by elongation in selected fragment of Nasielsk commune Source: own elaboration based on data from land and building register 
The specified parameters considerably hinder the development of both the settlement and the single-family residential function. Plots with excessive elongation contribute to a decrease in the profitability of agricultural production (among other things) due to side losses. The width of the plots also makes the development of new agricultural settlements impossible. Due to the low efficiency of agriculture, the residents are increasingly abandoning agricultural activity. However, single-family housing development is very difficult and, in many cases, impossible. In many cases, the widths of the plots are smaller than the minimum parameters required for single-family housing development (approximately a 20-25-m width in the front elevation). The building development of plots with smaller widths causes excessive intensification that is characteristic of urbanized areas. Therefore, the insufficient widths of the plots force a change in the current building development layouts through the construction of internal roads along the balks and transverse secondary divisions of the plots. The occurring changes result in transformations of the current traditional layouts of the rural building development and destroy the natural open landscape. The occurring changes in the building development layout are observed in the villages of Pieścirogi Nowe and Pieścirogi Stare, among others.

\section{Summary and Conclusions}

The defective structure of registered plots has an unfavorable effect on the development of the study area. The analyses showed that the plots are fragmented (the average surface area of a plot in a farm amounts to $1.5 \mathrm{ha}$ ) and excessively elongated (average elongation - 1:11). Such plot parameters make the development of agriculture and obtaining land for investment purposes (including construction) difficult. The low effectiveness of the agricultural activity caused by the land layout of farms and parameters of the agricultural plots leads to the requalification of arable land to building plots, which is clearly indicated by the local spatial development plans. The trend is particularly evident in villages with well-developed transportation systems (particularly, railway systems). The parameters of plots allocated for single-family housing development, however, do not meet their requirements. Adapting land under the current agricultural use for new functions causes changes in the traditional layouts of building development in the landscape. Such progressing urbanization of agricultural land leads to disturbances in the spatial order. An improvement of such a state could be obtained through a complex spatial policy. The consolidation and exchange of arable land would help identify and increase agricultural production profitability, which still constitutes the primary direction of the commune's development. In areas where single-family housing development has occurred to a considerable degree, activities would need to be undertaken towards a more detailed specification of the rules of introducing new functions and changes 
in the spatial structure of the plots through adjustments of the shapes and surface areas of the plots with the application of a procedure of division or the consolidation and division of land properties.

\section{References}

[1] Halamska M.: Transformacja wsi 1989-2009: zmienny rytm modernizacji. Studia Regionalne i Lokalne, nr 2(44), 2011, pp. 5-25.

[2] Zegar J.: Refleksje nad ewolucja wsi. Wieś i Rolnictwo, nr 3(140), 2008, pp. 37-43.

[3] Chmielewski J.: Teoretyczne przesłanki budowania systemu planowania przestrzennego na poziomie lokalnym. [in:] Maciejwska A. (red.), Wspótczesne uwarunkowania gospodarowania przestrzenią: szanse i zagrożenia dla zrównoważonego rozwoju: społeczny wymiar gospodarowania przestrzenia, Gospodarka Przestrzenna - Wydział Geodezji i Kartografii Politechniki Warszawskiej, t. 6, Oficyna Wydawnicza Politechniki Warszawskiej, Warszawa 2014, pp. 33-54.

[4] Ziobrowski Z., Pijanowski J.M. (red.): Nowe zadania planowania miejscowego w kształtowaniu i zagospodarowaniu przestrzennym obszarów wiejskich. Instytut Rozwoju Miast, Kraków 2008.

[5] Pijanowski J.M.: Systemowe ujęcie planowania i urządzania obszarów wiejskich $w$ Polsce. Zeszyty Naukowe Uniwersytetu Rolniczego im. Hugona Kołłątaja w Krakowie. Rozprawy, z. 386, Wydawnictwo Uniwersytetu Rolniczego, Kraków 2013.

[6] Woch F.: Organizacja przestrzenna gospodarstw rolniczych oraz jej wptyw na efektywność gospodarowania. Studia i Raporty IUNG-PIB, z. 7, 2007, pp. 117-137.

[7] Hopfer A., Urban M: Geodezyjne urzadzenia terenów wiejskich. PWN, Warszawa 1975.

[8] Janus J., Taszakowski J.: Wybrane parametry rozdrobnienia gruntów w powiecie myślenickim. Infrastruktura i Ekologia Terenów Wiejskich, nr II/3, 2014, pp. 679-692.

[9] Noga K.: Metodyka oceny struktury przestrzennej gruntów gospodarstw rolnych przed i po scaleniu. [in:] Scalenia gruntów podstawa rozwoju obszarów wiejskich rozdrobnionego rolnictwa południowo-wschodniej Polski, Zeszyty Towarzystwa Rozwoju Obszarów Wiejskich, TROW, Rzeszów 2005, pp. 30-47.

[10] Woch F.: Optymalne parametry rozłogu gruntów gospodarstw rodzinnych dla wyżynnych terenów Polski. Pamiętnik Puławski, t. 127, 2001, pp. 105.

[11] Leń P.: Patchwork of Land Ownership as Barrier to Development of Rural Areas. Geomatics and Environmental Engineering, vol. 11, no. 3, 2017, pp. 85-96.

[12] Leń P., Mika M.: The Impact of Socio-Economic Factorson the Size of the External Plot Patchwork - a Case Study of Brzustowiec Village in the Eódzkie Voivodship. Geomatics and Environmental Engineering, vol. 10, no. 2, 2016, pp. 43-51. 
[13] Bielska A, Leń P. (red.): Scalenia gruntów determinantem wielofunkcyjnego rozwoju obszarów wiejskich. Wyższa Szkoła Inżynieryjno-Ekonomiczna, Rzeszów 2015.

[14] Dawidowicz A., Klimach A.: The Development of Local Land Information Systems in the Rural Municipalities. Geomatics and Environmental Engineering, vol. 11, no. 1, 2017, pp. 33-46.

[15] Krzyk P.: Strukturalne i krajobrazowe aspekty przemian wiejskich jednostek osadniczych a planowanie przestrzenne. Problemy Rozwoju Miast, z. 2, 2010, pp. 25-34.

[16] Żarska B.: Modele ekologiczno-przestrzenne i zasady kształtowania krajobrazu gmin wiejskich. Wyd. SGGW, Warszawa 2006.

[17] GUS: Bank danych lokalnych, [on-line:] https://bdl.stat.gov.pl/BDL.

[18] Studium uwarunkowań $i$ kierunków zagospodarowania przestrzennego miasta i gminy Nasielsk. Uchwała nr LIII/394/10 Rady Miejskiej w Nasielsku z dnia 10 listopada $2010 \mathrm{r}$.

\section{Ograniczenia w rozwoju obszarów wiejskich wynikające $\mathrm{z}$ wadliwej struktury działek ewidencyjnych}

Streszczenie: Obszary wiejskie od wieków podlegają nieustannym przeobrażeniom. Obecny kształt sieci osadniczej i obraz polskiej przestrzeni są wynikiem szeregu zmian ustrojowych, prawnych oraz procesów ekonomicznych i społecznych. Wraz z rozwojem cywilizacyjnym zmianie ulegały czynniki warunkujące lokalizację nowej zabudowy mieszkaniowej, jak również funkcja pełniona przez obszary wiejskie. Współcześnie na obszarach wiejskich zwiększeniu ulega rola pozarolniczych funkcji produkcyjnych i funkcji konsumpcyjnych, co odbywa się kosztem malejącego udziału produkcji rolniczej.

Celem badań było określenie, w jakim stopniu struktura działek ewidencyjnych ogranicza możliwości rozwoju różnych funkcji na obszarach wiejskich. Badania przeprowadzono w gminie Nasielsk. Zbadano dokumenty planistyczne, określając kierunki rozwoju gminy, przeanalizowano strukturę wszystkich działek ewidencyjnych, a także określono ich powierzchnię i kształt. Określono rozłóg wybranych gospodarstw rolnych, uwzględniając powierzchnię gospodarstwa, liczbę działek, ich powierzchnię oraz kształt.

Z przeprowadzonych badań wynika, że wadliwa struktura działek ewidencyjnych nie tylko w znacznym stopniu ogranicza rozwój rolnictwa, ale utrudnia również racjonalne zagospodarowanie działek przeznaczonych pod zabudowę. Dodatkowo ułatwia naturalną sukcesję leśna, co jest korzystne z przyrodniczego punktu widzenia, ale niewątpliwie utrudnia wykorzystywanie gruntów rolnych.

Słowa

kluczowe: Nasielsk, rozwój obszarów wiejskich, struktura działek ewidencyjnych 